\title{
Normes, moyennes et variations; ethnologie et archéologie
}

\author{
CpenEdition \\ Journals \\ Édition électronique \\ URL : https://journals.openedition.org/tc/630 \\ DOI : $10.4000 /$ tc. 630 \\ ISSN : 1952-420X \\ Éditeur \\ Éditions de l'EHESS
}

Édition imprimée

Date de publication : 1 septembre 1994

ISSN : 0248-6016

Référence électronique

" Normes, moyennes et variations; ethnologie et archéologie », Techniques \& Culture [En ligne], 21 |

1994, mis en ligne le 30 décembre 2005, consulté le 29 septembre 2022. URL : http://

journals.openedition.org/tc/630 ; DOI : https://doi.org/10.4000/tc.630

Ce document a été généré automatiquement le 29 septembre 2022.

Tous droits réservés 
Normes, moyennes et variations; ethnologie et archéologie 